NBER WORKING PAPER SERIES

\title{
THE AGE DISCRIMINATION IN EMPLOYMENT ACT AND THE CHALLENGE OF POPULATION AGING
}

\author{
David Neumark \\ Working Paper 14317 \\ http://www.nber.org/papers/w14317 \\ NATIONAL BUREAU OF ECONOMIC RESEARCH \\ 1050 Massachusetts Avenue \\ Cambridge, MA 02138 \\ September 2008
}

This research was supported by the AARP. The AARP had no control over its content, for which I am fully responsible. I am grateful to Ronald Edwards for providing information on EEOC enforcement activity, and to Scott Adams, Joanna Lahey, and anonymous reviewers for helpful comments. The views expressed herein are those of the author(s) and do not necessarily reflect the views of the National Bureau of Economic Research.

NBER working papers are circulated for discussion and comment purposes. They have not been peerreviewed or been subject to the review by the NBER Board of Directors that accompanies official NBER publications.

(C) 2008 by David Neumark. All rights reserved. Short sections of text, not to exceed two paragraphs, may be quoted without explicit permission provided that full credit, including $\odot$ notice, is given to the source. 
The Age Discrimination in Employment Act and the Challenge of Population Aging David Neumark

NBER Working Paper No. 14317

September 2008

JEL No. J14,J71,J78

\section{$\underline{\text { ABSTRACT }}$}

This paper reviews evidence on age discrimination in U.S. labor markets and on the effects of the Age Discrimination in Employment Act (ADEA) in combating this discrimination. It focuses on the challenge of population aging facing the U.S. economy in coming decades. Combating age discrimination is likely to help in meeting this challenge by encouraging employment of older individuals. But the paper also explores how rapid aging of the population protected by the ADEA might inhibit the ADEA's effectiveness, and raises questions about possible changes in age discrimination policies and enforcement that could enhance the ability of the ADEA to mitigate some of the adverse consequences of population aging.

David Neumark

Department of Economics

3151 Social Science Plaza

University of California, Irvine

Irvine, CA 92697-5100

and IZA

and NBER

dneumark@uci.edu 


\section{Introduction}

The Age Discrimination in Employment Act (ADEA) was passed 40 years ago. The original Act prohibited discrimination on the basis of age for those aged 40-65. Subsequent amendments raised the upper age limit to 70 and then eliminated it altogether, ending mandatory retirement for nearly all workers. In this review I take stock of how successful the ADEA has been at achieving its intended goals. I also discuss important changes in the context in which the ADEA will operate, to assess how well the ADEA will continue to achieve its goals in that changing context, and to contemplate how it might be made more effective. In particular, I focus on the challenges posed by an aging population in the United States. I consider the role the ADEA - perhaps with some adaptation - might play in meeting these challenges, as well as the potential consequences of an aging population for the effectiveness of the ADEA. My review touches on many aspects of the ADEA, but emphasizes the issues that seem most relevant to the effectiveness of the ADEA in the context of an aging population. ${ }^{1}$ Because these are primarily economics issues, the review emphasizes findings from the economics literature.

\section{Assessing the ADEA in Light of the Aging of the U.S. Population}

The aging of the population in the United States will pose significant public policy challenges over the next few decades. Most significantly, population aging means that public policy must be increasingly concerned with the employment of older individuals, because continued employment implies lower dependency ratios, greater income, more tax revenues, and decreased public expenditures on health insurance, retirement benefits, and income support (depending on the age of the individual and their economic circumstances). In light of these concerns, perhaps the most important lens through which it is useful to view the ADEA is its potential to encourage the continued employment of those older Americans who desire to continue working, or, conversely, to discourage discriminatory behavior that might reduce 
employment of these individuals. The potential for the latter type of discrimination is real, although as discussed in greater detail later in this paper, harder to establish in fact.

Until recently, the large cohorts of the Baby Boom were passing through the prime ages of adulthood. As shown in Figure 1, across the years 1990 and 2000, the share of the population in the 45-64 range grew somewhat, and the share in this age group was quite a bit larger than the share in the group aged 65 and over. Those aged 45-64 were likely to be strongly affected by the ADEA, which covered workers aged 40 and over. On the other hand, in the next few decades (after 2010) there will be a declining share aged 45-64 and a rapidly increasing share aged 65 and over, with the two shares approaching equality by the middle of the century. These shifts in the age structure of the population suggest that to the extent that the ADEA has a role to play in maintaining or encouraging employment of older workers, its impact on those beyond what has been considered the "normal" retirement age of 65 will become relatively more important than it has been in the past. This has important implications for age discrimination policy.

First, employment rates of those under age 65 are already quite high (in 2006, 77.8 percent for 20-44 year-olds, and 71.9 percent for 45-64 year-olds); in contrast, employment rates of those aged 65 and over are low (15 percent in 2006). ${ }^{2}$ Thus, if the ADEA has the potential to boost employment of older individuals, its greatest potential lies among those past the normal retirement age, both because of the population shift into this age group, and because of its low baseline employment rate. Second, given that ADEA enforcement has tended to focus on terminations, it seems likely that, in recent decades, its impact has centered more on continued employment of those younger than the normal retirement age. Without suggesting that this is becoming less important, it seems clear that if age discrimination plays any role in suppressing employment of those older than age 65, then figuring out how the ADEA can contribute to rooting out discrimination against these older individuals becomes of prime policy importance. 
Second, a sizable share of any increases in employment among those aged 65 and over is likely to come not from continued employment in their long-term careers, but rather from parttime or shorter-term jobs, perhaps at subsequent employers, in the form of what has sometimes been labeled “partial retirement” (e.g., Gustman and Steinmeier 2000) or bridge jobs (e.g., Cahill, Giandrea, and Quinn 2005). On the other hand, Abraham and Houseman (2005) present evidence that older workers face difficulties in moving from a longer-term career job to new employment characterized by partial retirement, and may consequently end up retiring before they might otherwise have done. Abraham and Houseman do not necessarily attribute these problems to age discrimination in hiring, but they suggest it may be a contributing factor. If older individuals are increasingly likely to look for a bridge job after leaving their full-time career, which Cahill et al. predict, then the focus of ADEA enforcement on terminations might not serve the nation as well going forward. Instead, it might become relatively more important to figure out how to ensure that age discrimination also does not deter hiring of older individuals seeking employment subsequent to leaving career jobs. ${ }^{3}$

The third implication of an aging population for age discrimination policy is that efforts to reduce age discrimination contrast with other policy responses to an aging population in an important way. In particular, policies that reduce incentives for retirement, increase retirement ages by fiat, and reduce the value of private and public pensions, especially after some retirement-related decisions have been made, likely result in reduced economic well-being for older individuals. In contrast, to the extent that age discrimination acts to deter employment of older individuals, efforts to reduce its influence - assuming they do not impose undue costs - can increase the welfare of those individuals who wish to keep working and are enabled to do so, while at the same time helping to achieve the broader goal of keeping Americans at work longer (not to mention protecting the civil rights of older individuals). Moreover, the ability of older 
individuals to respond to policy changes intended to increase incentives for employment will be enhanced if discrimination that otherwise deters this employment can be reduced; this implies that more effective efforts against age discrimination may enable policymakers to meet the challenges of an aging population with less drastic changes in retirement policies and incentives.

On the other hand, the ADEA also has its critics. Some charge that age discrimination is overstated and that the ADEA instead simply benefits older workers at the expense of other workers. Others stake out a less extreme view, but nonetheless argue that the ADEA has adverse unintended consequences (e.g., Friedman 1984; Lahey, forthcoming). These more critical perspectives suggest that an aging population may exacerbate the problems generated by the ADEA, becoming more a hindrance than a help in coming decades. Consequently, this paper also assesses the evidence pertaining to these critiques of the ADEA. III. Equal Employment Opportunity Commission (EEOC) Enforcement Activity

The EEOC is responsible for federal enforcement of the ADEA. ${ }^{4}$ An individual wanting to pursue a claim must first file a charge with the EEOC (or, in states with similar statutes, with state Fair Employment Practices (FEP) commissions or agencies). ${ }^{5}$ The EEOC may choose to investigate based on the facts presented, dismissing the case if it does not see a violation of the law. For charges not dismissed, the EEOC can seek a settlement or mediation, and if these are unsuccessful it may choose to file suit, which happens in a very small share of cases - in general for larger cases likely to involve a sizable class. The individual retains a right to sue after the EEOC process has run its course, regardless of the EEOC's determination. Information on charges brought to the EEOC and on EEOC litigation provides some idea of the landscape of enforcement of the ADEA, and how it compares to other anti-discrimination laws. ${ }^{6}$

Tables 1 and 2 give information on the types of discrimination that are alleged in charges received by the EEOC and in EEOC litigation. Table 1 reports the breakdown of bases or issues 
alleged in charges in total and under the ADEA, the Americans with Disabilities Act (ADA), and Title VII (which covers discrimination based on race, sex, ethnicity, etc.). Table 2 gives similar information on the types of discrimination alleged in suits brought by the EEOC in 2006. These are grouped not by statute, but by the type of discrimination alleged. Table 1 shows that charges related to discharges and layoffs are more common in ADEA cases than in Title VII cases, while Table 2 shows that they are also more common in age cases than in race or sex cases that are litigated. Charges related to involuntary retirement, while not common, are largely confined to ADEA claims, while wage cases are relatively uncommon - not surprisingly, given that older workers are on average more highly paid than younger workers, although obviously this masks a great deal of heterogeneity.

The tables also show that hiring cases, in general, are much less common than discharge or layoff cases, although they do constitute a larger share of ADEA charges than of ADA or Title VII charges, or of issues alleged in race and sex cases that are litigated. The paucity of hiring relative to discharge or layoff cases could reflect the actual nature of the types of discrimination being experienced. But it may also reflect consequences of the legal structure. First, hiring cases are more difficult to prove, because it is more difficult to identify a class of affected workers. In contrast, in discharge or layoff cases the class typically consists of a group of workers previously employed at a firm. Second, damages may be considerably higher in discharge or layoff cases, since workers lose jobs, and for older workers the job may have been relatively high paying and there is evidence of difficulties finding new jobs; in addition, there can be substantial lost pension wealth accruals. In contrast, damages in a hiring case may be quite small, because an individual not hired by one employer may soon be hired subsequently by another employer. Finally, injunctive relief in hiring cases - hiring the worker who filed the claim - is unlikely to be attractive to a plaintiff. ${ }^{7}$ 
These barriers to pursuing claims of hiring discrimination are potentially quite important in light of the evidence noted earlier that workers aged 65 and over, often working in jobs subsequent to a long-term career, are an increasing source of potential employment growth. If the distribution of cases under the ADEA reflects “structural” problems in combating age discrimination in hiring relative to discharges or layoffs, then the ADEA may become a less useful tool in the future than it has been in the past, when the bulge of protected workers was in the age range in which they were likely to be employed in - and perhaps fired from - their career jobs.

\section{Key Issues and Recent Changes in Interpreting the ADEA}

Two recent changes in the interpretation of the ADEA may be particularly significant for future developments, and influence how well the ADEA serves the nation's needs in coming decades. First, in 2004 the EEOC approved a rule regarding health benefits that eased the restrictions imposed by an earlier ruling (Erie County Retiree's Association v. County of Erie 2000). The 2004 rule, subsequently upheld by the courts, made it easier for employers to coordinate retiree health benefits with Medicare - mainly by not requiring employers to show that the benefits are identical to benefits received by early retirees who are not eligible for Medicare. It was a response to fears among employer and worker organizations that the Erie ruling would lead to the elimination of retiree health plans to avoid the risk of violating the ADEA. ${ }^{8}$

Although this ruling applies to retirees, related issues can potentially arise for employees aged 65 and over who are eligible for Medicare. Currently, EEOC regulations allow employers to coordinate with Medicare, as long as doing so does not result in a reduction of benefits of any type. ${ }^{9}$ However, as indicated by the difficulties to which the EEOC responded after the Erie decision, employers may be wary of trying to coordinate Medicare coverage with their group 
health plans for employees aged 65 and over. I return to this issue below.

Second, because of the "reasonable factors other than age" exception, which recognizes that factors other than age can lead to the appearance that age drove an employment-related decision, a sequence of court rulings - most notably the U.S. Supreme Court in Hazen Paper Co. v. Biggin, in 1993 - had made it considerably more difficult to use disparate impact as the basis of age discrimination claims. ${ }^{10}$ However, in Smith v. City of Jackson (2005), the Supreme Court ruled that the ADEA allows disparate-impact claims, although the standard for such a claim is higher than in Title VII cases, requiring that plaintiffs also be able to identify specific practices that have an adverse impact on older workers, and putting less burden of proof on the defendant to establish that there is a business justification for the practice. ${ }^{11}$ It is likely that this decision will make it easier for plaintiffs to pursue age discrimination claims. This may be particularly true with regard to hiring of individuals in the older age ranges that will see population growth in the decades ahead, given that hiring cases are likely to argue based on disparate impact.

\section{$\underline{\text { V. Evidence on Age Discrimination }}$}

If age discrimination persists in U.S. labor markets, then continued vigilance with regarding to enforcing the ADEA is likely to prove helpful in meeting the challenges of population aging - especially if coupled with creativity in thinking about how the law and its enforcement might be modified to better meet these challenges. On the other hand, there is research that contends that enforcement of the ADEA has some harmful effects for older workers, or for economic efficiency generally, and in the extreme argues that the ADEA does more harm than good and perhaps even addresses a non-existent age discrimination problem. Thus, in assessing the effectiveness of the ADEA, it is important to focus on both the need for policies to combat age discrimination and on the effectiveness of these policies (if they are needed). This section, which considers recent evidence on age discrimination, and the next 
section, which looks at the effects of laws prohibiting age discrimination, takes up these issues.

Overall, it is no easy matter to establish the existence of age discrimination, except for rare cases of overt expressions of discriminatory intent. This is little different from the case for race and sex discrimination, about which labor economists (and others) still argue. And detecting evidence of age discrimination is a bit more difficult because there are legitimate, nondiscriminatory reasons why age may affect labor market outcomes - principal among them considerations suggested by the human capital model.

Prior to the ADEA, two sets of facts were emphasized as evidence of age discrimination, both of which pertained to discrimination in hiring. First, Miller (1966) argued that older workers who lost their jobs had more difficulty finding new jobs than did prime-age workers, based on both higher unemployment rates and longer durations of unemployment. Second, the original U.S. Department of Labor report (1965) arguing for passage of the ADEA cited evidence from the late 1950's of widespread prevalence of upper age limits for new hires. The report interpreted this overt discriminatory behavior as stemming form incorrect negative stereotypes regarding older workers. ${ }^{12}$

The passage of the ADEA has surely resulted in the elimination of explicit upper age limits for jobs. It is less clear that longer unemployment durations for older individuals disappeared. As shown in Table 3, BLS data indicate that older individuals are still considerably more likely to have long unemployment durations. However, these longer durations do not necessarily reflect discrimination against older workers. Moreover, unemployment rates of older individuals are lower than those of other age groups, and substantially lower than those of young individuals. This remains true even if we count discouraged workers as unemployed, although it is possible that other older individuals simply decide to retire because of poor job prospects and no longer report themselves as available to work or discouraged. ${ }^{13}$ 
It is harder to establish what has happened with respect to negative stereotypes about older workers. A large body of research studies whether there are negative stereotypes about older workers that appear to adversely affect them in the labor market, with many researchers concluding that there is such evidence (e.g., Finkelstein, Burke, and Raju 1995; Kite et al. 2005). More recently, however, Gordon and Arvey (2004) suggest that negative age stereotypes may have declined, perhaps due to EEOC policy as well as improved relative performance of older workers among more recent cohorts. If EEOC policy has helped to break down negative stereotypes by leading to more objective appraisals of workers, then the law may have become less necessary, unless in its absence employers would resort to using age as a screening device. On the other hand, we do not really know from the existing research whether negative stereotypes have declined with respect to those in the 65 and over age category who will be an increasing share of older potential workers in coming decades. If past policy has done little to address stereotypes about this older group, then it may still have a quite important role to play.

Ultimately, though, negative stereotypes are important only insofar as they affect labor market outcomes, and age differences in labor market outcomes do not necessarily imply age discrimination. In addition, there may be reasons for age discrimination other than negative stereotypes. Thus, to better understand the role of age discrimination in labor markets, we require evidence on age-related differences in labor market outcomes that try account for nondiscriminatory explanations of these differences.

In recent years "audit studies," in which pairs of matched applicants are sent to apply for jobs, and outcomes are compared, have been used to test for age discrimination; in this context, applicants are matched on all characteristics except for age. A closely related method is a “correspondence study," which relies instead on sending out resumes and measuring outcomes in terms of being invited in for an interview or other expressions of interest in hiring. ${ }^{14}$ The first 
versions of these studies for the United States were by Bendick and co-authors, who did a correspondence study of hiring in three white-collar occupations (Bendick, Jackson, and Romero 1996), and an audit study in the Washington, DC metropolitan area of hiring in entry-level management and sales positions (Bendick, Brown, and Wall 1999). Both studies found evidence consistent with age discrimination against older workers.

However, a fundamental problem with using these methods to study age discrimination is that there is no natural way to make older and younger workers identical in all respects other than age. We would expect an older worker to have more experience than a younger worker. If the information on the resumes or conveyed by the testers reveals this, then we might find more favorable outcomes for the more-experienced worker, irrespective of the other influences of age. To account for this, Bendick et al. try to hold human capital constant by giving the older and younger applicants (aged 32 and 57) the same number of years (ten) in the occupation for which they were applying, with the older applicants indicating that they had been out of the labor force raising children, working as a high school teacher, or in the military, depending on the job for which they were applying and the sex of the applicant pool. But this other fictitious experience could be viewed negatively by employers, as perhaps suggesting that interests lie elsewhere, work is not a priority, etc., and this could explain adverse outcomes for older applicants.

A more recent correspondence study by Lahey (2008) focuses on women in two urban labor markets, and also finds evidence consistent with age discrimination. Lahey attempts to address the difficulty of making older and younger applicants alike in a number of ways. She studies women, for whom she suggests time out of the labor force (even if only inferred by employers) is less likely to be a negative signal of ability, motivation, etc., than for men. She also studies entry-level jobs (really the only possibility in correspondence studies), so one might think previous experience is a bit less of an issue. 
Perhaps most important, the resumes she uses include only a 10-year job history, which Lahey argues is the “current resume standard.” However, it is unclear how the "missing” history for older applicants affects employers’ assessments. If all employers ever see are resumes with 10-year job histories, then they can only make assumptions about what the older applicant was doing in the long period not covered by the job history. If the employer assumes the applicant was working, then the presumption might be that she has more experience, perhaps working in favor of older applicants. But if the employer assumes the applicant was not working, this could be viewed as a negative signal about productivity. On the other hand, if employers expect a longer job history for older applicants, then its absence may be viewed as a negative signal about older applicants. Lahey cites conversations with three human resource managers, stating: “They all said that ten-year histories are the current gold standard for resumes, although they get many resumes that do not look like the standard” (Lahey 2008:34, note 10). However, this does not establish that earlier job history information would not convey useful information, or that its absence would not be perceived negatively. Moreover, since younger individuals are much more likely to be applying for jobs than are older workers, perceptions regarding the so-called "goldstandard” for resumes may be shaped by the fact that the sample of resumes that tends to be observed is biased toward younger applicants who rarely have more than ten years of experience.

This discussion emphasizes that there are inherent limitations in using audit studies to study age discrimination. Nonetheless, these limitations do not necessarily bias the results towards finding evidence of discrimination against older workers. In sum, the audit/correspondence studies should probably be viewed as providing at most suggestive evidence of age discrimination in hiring.

Although recent empirical work has focused on hiring, it is clear from ADEA enforcement activity that there are also at least allegations of age discrimination based on 
discharges, layoffs, promotions, and other outcomes. Adams (2002) tries to assess evidence on how discrimination in promotions affects workers. Using self-reported information on perceived age discrimination in the HRS, he finds that older workers reporting that their employer gives preference to younger workers in promotions have lower wage growth and a reduced expectation of working past the early or normal social security retirement ages. Of course self-reports can reflect negative outcomes other than discrimination, which Adams tries to account for by including controls for the perceived work environment and fairness of the respondent's pay. Although in light of this problem evidence from self-reports is far from decisive, this research provides suggestive evidence that employers may discriminate in promotions, with deleterious effects on older workers, including leaving the labor force. ${ }^{15}$

The preceding review of the literature on age discrimination is not comprehensive. But my view of the overall evidence (see also Neumark 2003 and 2008) is that it is more likely than not that labor markets were and still are characterized by discrimination against older workers. ${ }^{16}$ With respect to the issue of population aging, and in particular the burgeoning share of the potential workforce aged 65 and over, an important limitation of the existing literature on age discrimination is that it does not focus on this group. Indeed, the research typically focuses on “younger” older workers, or broader older age groups extending down to younger ages.

\section{The Effects of the ADEA and State Age Discrimination Laws}

Neumark and Stock (1999) study the effects of both the federal ADEA and state laws barring age discrimination. State variation prior to the federal variation is useful in disentangling the effects of the legislation from other changes affecting older versus younger individuals in the same period, such as social security, pensions, and health. A potential limitation of this approach is that state laws and federal laws do not necessarily have the same effects. However, the results suggest - as do those in Adams (2004), discussed below - that quite similar answers are obtained 
from variation in state laws and variation in federal laws.

Using Census data covering 1940-1980, for white men, Neumark and Stock find that age discrimination laws boost employment rates of the entire group of protected workers only slightly; but employment rates of protected workers aged 60 and over are increased substantially (by 6 percentage points). However, prohibitions of mandatory retirement did not boost employment of older workers affected by the change, although the data are not very informative about this issue. Adams (2004) uses a similar research design, focusing on the mid-1960s when a number of states passed age discrimination statutes and then the federal legislation took effect; he uses CPS data and also studies white men. He finds larger employment effects for protected workers as a whole, with a 2.75 percentage point increase in their employment rate. For those aged 60 or 65 and older, he finds more substantial increases of 3.6 to 4.1 percentage points. The results are similar for the effects of state anti-discrimination statutes passed prior to the ADEA and the introduction of the ADEA in the other states. He also finds that age discrimination laws are associated with lower probabilities that older protected individuals are retired.

Adams also uses this approach to try to study how age discrimination laws affect hiring (as an increase in hiring could explain lower retirement). However, his analysis is hampered because he does not use longitudinal data. His best evidence examines how age discrimination laws affect the probability that individuals not employed at some time during the previous year, but looking for work, are employed in the current year. The results point to negative but insignificant effects on hiring of protected workers overall, although a more disaggregated analysis suggests a large (16 percentage point) negative hiring effect for the oldest protected individuals (aged 65 and over), significant at the 10-percent level. Although in general this and other evidence he presents on hiring is weak, Adams concludes that "One thing is clear ... There is no evidence that suggests that there are positive effects for protected workers” (Adams 
2004:237).

Lahey (forthcoming) uses a different identification strategy to estimate the effects of age discrimination laws. In particular, she focuses on the effects of state age discrimination laws relative to the federal law. She argues that workers in states with their own age discrimination laws are protected by stronger laws than are workers in states without their own laws, for two reasons. First, in states with their own laws workers have longer to file age discrimination claims. ${ }^{17}$ And second, FEP agencies in these states may be able to process claims more quickly than the EEOC; however, she presents no evidence that states are more effective or efficient than the EEOC. It is also important to clarify that what Lahey is calling an effect of an age discrimination law might more correctly be thought of as an effect of lengthening the period during which one can file an age discrimination claim (and having the option to file with the state as well), which simply may not be the same thing. ${ }^{18}$

Looking first at the period prior to 1978, before the Department of Labor gave administrative responsibility for ADEA enforcement to the EEOC, Lahey finds little evidence that state laws affected older workers. In the subsequent period, however, her evidence suggests that state age discrimination laws reduced weeks worked of white men older than 50 years of age, made such individuals more likely to be retired, and reduced hiring of them (which she measures better than Adams by using matched CPS files). Note that the employment (actually, weeks worked) results and the retirement results are the opposite of those in Adams' work, and the employment results also contrast with those in Neumark and Stock. In addition, the conclusions about adverse hiring effects are stronger than those Adams draws. She suggests that because the ADEA makes it difficult to terminate the employment of older workers, it ends up deterring their hiring in the first place. This may be exacerbated by the difficulty of bringing suit over age discrimination in hiring, as discussed earlier. 
Lahey characterizes the pre-1978 period as one in which the ADEA had little effect, which is why she splits the sample into the pre-1978 period and the subsequent period. However, the results in Neumark and Stock indicated little difference between the effects of the ADEA on employment of older covered workers in the pre-1978 and post-1978 periods, with at most slightly larger impacts in the latter. Nonetheless, if we were to accept Lahey's characterization of the federal law as becoming effective (to a large extent) in 1978, then there is an important source of identifying information that she ignores - namely, the extension of the federal law to states without anti-discrimination laws. Her evidence shows that between the pre1978 and the 1978-1991 period, the employment of worker over 50 years of age fell in states with their own age discrimination laws, relative to the states without their own laws (her Table 2); there was no such change for those aged 50 and under. This implicit difference-in-differencein-differences estimator suggests that when the federal law became more effective, employment of those older than age 50 increased precisely in the states that did not previously have state age discrimination laws. This would seem to imply that age discrimination laws - at least the federal law - boosted employment of protected workers, contrary to Lahey's conclusions.

Overall, then, I do not regard this study as establishing that age discrimination laws act to deter hiring of older workers. However, the logic of the argument, and hence the hypothesis that age discrimination laws deter hiring of older workers, may still be correct. And recall that the evidence in Adams (2004) does not suggest any beneficial hiring effects of age discrimination laws, and perhaps the opposite, especially for those aged 65 and over.

The evidence regarding hiring is discouraging for two reasons. First, as noted earlier, the clearest indications of age discrimination prior to the ADEA, and during the period it has been in effect, concern hiring discrimination. Yet the evidence points to no impact of age discrimination laws with regard to hiring, and possibly adverse effects. Second, the evidence on changing 
population structure and the labor force behavior of older individuals suggests that the most significant challenge in coming decades concerns barriers to hiring of older workers. If, in fact, age discrimination laws - and the ADEA in particular - seem to deter hiring of older workers, then it seems difficult to see how the ADEA, at least as it is currently implemented and enforced, is going to help solve this problem. Moreover, even if the ADEA (and state discrimination laws) do not deter hiring of older workers, they may do little if anything to help encourage such hiring or to break down discriminatory barriers to such hiring.

Neumark and Stock (1999) also focused on the longer-term effects of age discrimination laws. In Lazear's (1979) seminal model of the employment relationship, firms find it difficult or costly to monitor workers' effort, and hence use pay schemes to create incentives to work hard. In particular, workers and firms enter implicit long-term contracts that pay workers wages lower than their productivity when they are young, in order to motivate them to work hard, and make up the shortfall by paying workers wages higher than their productivity when they are older (more-tenured). ${ }^{19}$ The key implication of Lazear's model is that such implicit contracts lead to mandatory retirement, at the date when the present value of the streams of earnings and productivity are equal. Furthermore, a contract with mandatory retirement is acceptable to workers ex ante, because the contract leads to higher productivity and earnings. However, mandatory retirement occurs when the wage a worker is paid exceeds the value of their leisure time, so at the mandatory retirement age workers find mandatory retirement undesirable, and it may therefore appear discriminatory. Based on this model, Lazear was strongly critical of the ADEA, focusing on amendments that raised the age of mandatory retirement and subsequently eliminated it. In particular, he conjectured that the ADEA would serve mainly to give a windfall to older workers through the elimination of mandatory retirement - which was not discriminatory in the first place - while imposing longer-run efficiency costs. 
Neumark and Stock (1999) re-examined this critique of the ADEA. They began by considering the other problem posed by Lazear contracts - the incentive for firms to renege on these long-term contracts when workers are relatively older, terminating their employment before the mandatory retirement date and hence "cheating" workers out of the promised higher wage payments. This behavior that would likely be construed as age discrimination - and could explain the high incidence of termination charges and cases under the ADEA ${ }^{20}$ They argue that the main effect of the ADEA could have been to deter this kind of reneging, strengthening the ability of workers and firms to take advantage of these contracts, ${ }^{21}$ and they present evidence suggesting that this was the effect of age discrimination laws, in the form of steepening earnings profiles for cohorts entering the labor market subsequently. Thus, the evidence presented in Neumark and Stock casts the effects of age discrimination laws in a more favorable light, arguing that such laws help to resolve problems with respect to terminations on career jobs.

At the same time, Neumark and Stock's (1999) findings attest to the importance of Lazear contracts. As such, Lazear's model may also help in understanding hiring difficulties faced by older workers looking for employment subsequent to their career jobs. In order to create sufficient back-loading of pay to elicit effort from workers, an older worker seeking a new job may need to be paid much less than the wage on a longer-term career job he recently left. However, the worker may not be willing to accept such a low wage, especially a worker in his 60's, for example, who might have considerable uncertainty about how long he will work subsequently. Moreover, with relatively short expected tenure at the new job, losing the job may not be very costly to the worker, implying that an even lower initial wage may be needed to create the right incentives. This can explain why certain jobs may not be amenable to the hiring of older workers; indeed Hutchens (1986) and Hirsch, Macpherson, and Hardy (2000) present evidence suggesting that jobs with characteristics associated with Lazear-type contracts are in 
fact less likely to be those into which older workers get hired. This potential barrier to the hiring of older workers is problematic in light of the desirability of boosting hiring of older workers in coming decades.

Another issue related to Lazear contracts that bears on the coming challenge of population aging stems from the shift from defined-benefit (DB) to defined-contribution (DC) pension plans. ${ }^{22}$ Lazear (1979) originally argued that mandatory retirement is used to enforce termination of the employment relationship at the appropriate time. Later, though, he noted that a DB pension plan could be structured that will induce retirement at the same date, by setting the maximum present value of the pension to peak at that date (Lazear 1995). If employers previously used DB pension formulas to induce mandatory retirement, then as more and more workers arrive at older ages with DC plans, employers may find it more difficult to induce older workers to leave employment. It is possible therefore that the shift toward DC pension plans may lead to a need for increased vigilance regarding age discrimination in terminations of older workers. This has to be weighed against any other possible reasons for shifting the focus of age discrimination enforcement toward the hiring side. That is, the aging of the population - which this paper emphasizes - is not the only change buffeting U.S. labor markets, and attention must be paid to other trends that have implications for age discrimination legislation and enforcement. VII. Age Discrimination-Related Challenges on the Horizon

In this section, I touch briefly on what I see as two key issues that are likely to become increasingly important regarding age discrimination laws and employment of older individuals, focusing in large part, but not exclusively, on employment of those aged 65 and over.

\section{Health Care Costs}

The relentless increase in health care costs and the costs to employers of providing health insurance are well-known. Because health insurance costs are higher for older individuals and 
workers (Lahey 2007; Sheiner 1999), rising health insurance costs seem poised to become an increasing drag on employment of older individuals. ${ }^{23}$ As discussed earlier, the EEOC (following the Erie decision) made it easier to incorporate Medicare into health insurance packages for retirees without running afoul of the ADEA, by reducing concerns about equality of benefits between those under age 65 and those aged 65 and over who are eligible for Medicare. With a growing share of the potential workforce aged 65 and over in coming decades, being able to employ older workers and cover them through Medicare obviously becomes increasingly attractive.

One option worth considering is to extend EEOC rules regarding retirees to employees who are eligible for Medicare, making it easier for employers to cover workers eligible for Medicare under a combination of their own group health plans and Medicare, even if that might sometimes entail reductions in benefits and almost certainly would generate some differences in health insurance benefits for older and younger workers. Current rules stipulate that for employers with 20 or more employees, if workers are covered by employer-sponsored group health plans, the group plan is the primary payer and Medicare is the secondary payer covering expenses not covered by the group plan. ${ }^{24}$ Thus, under present Medicare rules employers could mainly cut health insurance costs for Medicare-eligible workers only by reducing group health benefits offered to older workers and letting Medicare pay these instead. A simpler solution would be to make Medicare the primary payer, in which case group health plans would not have to delineate benefit differences between those eligible and those not eligible for Medicare, and indeed as long as the group health plan paid any benefits not covered by Medicare that would be paid to younger workers, issues of differences in treatment of younger and older workers would not arise. The alternative is to continue to insist on equal benefits paid by employers, which could either reduce offerings of health insurance by employers that employ an older workforce, 
or simply discourage the employment of workers aged 65 and over. ${ }^{25}$

On the other hand, the current law allowing companies to offer health insurance to fulltime but not to part-time workers (working fewer than 20 hours per week) might help mitigate the effects of rising costs to employers of providing health insurance, among older workers looking for employment subsequent to their career jobs, who are largely looking only for parttime work and have Medicare coverage. At the same time, the ability to avoid providing health insurance to part-time workers might lead to more part-time work as health insurance costs rise (Baicker and Chandra 2005), including among older workers. Thus, rising health care costs coupled with difficulties of combining group health insurance plans and Medicare will likely pose problems for workers who reach age 65 and want to continue working full-time. Age and Disability

Because work-limiting disabilities rise with age (e.g., Stock and Beegle 2004), population aging implies that in coming decades more workers with age discrimination claims may also have the option of pursuing claims under the ADA as well as the ADEA. The ADEA, like Title VII, includes an exception for bona fide occupational qualifications that can, in limited circumstances, be used to justify a relationship between age and labor market outcomes. In contrast, the ADA offers no such exception. As a result, the ADA may offer greater protection to older workers suffering some of the milder adverse consequences of aging that, under the ADEA, might be grounds for discharge or failure to hire (Posner 1995), but still be judged as amenable to "reasonable accommodation" by employers, in the language of the ADA.

One implication of this line of reasoning is that population aging may interact with disability and protection under the ADA so as to provide more protection for older workers. However, the greater protection of older workers because of the ADA can cut both ways. Some research suggests that the ADA reduced employment among disabled individuals (Acemoglu and 
Angrist 2001; Deleire 2000), possibly stemming from both firing costs associated with wrongful termination suits, as well as difficulties in reducing discrimination in hiring or the costs of accommodating disabled workers. If this is in fact the case, then the likelihood that older workers are more likely to be disabled and hence able to file suit under the ADA, coupled with the possibility of greater success under the ADA than under the ADEA, may deter employers from hiring them even if they are not disabled at the time of hire, out of a fear that they will subsequently become disabled and impose firing costs.

Other research on the effects of state disability discrimination laws challenges the conclusions of the studies cited above, failing to find evidence of disemployment effects (Beegle and Stock 2003; Jolls and Prescott 2005). ${ }^{26}$ However, the research on disability laws does not focus on workers aged 65 and older. Thus, the evidence from this research may speak more to the consequences of disability-related discrimination laws for those with "traditional” disabilities unrelated to age rather than to those that are more the result of aging. In addition, what we face going forward is the existence of both age discrimination and disability discrimination laws, and the research discussed above does not estimate their joint impact.

Stock and Beegle (2004) study the joint impact of age and disability discrimination laws, based on state variation. They find that for disabled individuals aged 40-64, when the two types of laws are combined, the employment effect is negative, relative to an age discrimination law alone. Again, though, this evidence does not address those aged 65 and over. However, they present results for this age group that do not distinguish by disability status of the individual, and here they find marginally significant evidence of employment reductions overall, and relative to 40-64 year-olds. Thus, it seems that there is some likelihood that the increasing share of older and disabled individuals in the population, coupled with the availability of disability-related discrimination claims for a growing share of workers protected under the ADEA, could 
undermine some of the potentially beneficial effects of the ADEA as the population ages. VIII. Conclusions and Discussion

A number of conclusions can be drawn from the existing research on age discrimination and the effectiveness of the ADEA. First, there is little doubt that the ADEA was a response to age discrimination. This discrimination was more likely reflective of negative stereotypes about older workers than simply animus (“distaste”) towards older workers that affected hiring. It may also have reflected employers’ incentives to renege on long-term commitments to workers. Second, enforcement of the ADEA has focused on terminations much more than hiring. To some extent, this likely reflects the difficulties and potential rewards with regard to claiming discrimination in terminations versus hiring. On the other hand, there is reason to believe that there has been discrimination - as defined by the law - with respect to terminations. There is evidence suggesting continued discrimination against older individuals in hiring and other employment-related decisions such as promotions, although important challenges remain in establishing decisive evidence of age discrimination.

Age discrimination laws - both state laws and the ADEA - boost the employment of older protected workers. Although there is some contrary evidence on this point, it is less convincing. There is some evidence suggesting that banning mandatory retirement had little effect on employment of older workers, but also some evidence to the contrary, and the jury is probably still out; there is also some evidence that age discrimination laws reduced retirement. There is no evidence indicating that the ADEA increased employment via increased hiring, and it is possible that it reduced hiring of older workers, perhaps because of increased costs of terminating such workers. Finally, some evidence suggests that the principal effect of the ADEA was to strengthen the bonds leading to long-term employment relationships, by reducing the incentives for firms to terminate older employees who might be at the part of the employment 
relationship where pay is higher than productivity.

The conclusions just summarized are retrospective. This paper has also offered a more speculative, prospective assessment, exploring how well the ADEA is likely to serve in addressing the future challenge of population aging. This assessment and related considerations leads to a number of conclusions, and some thoughts about how age discrimination law might help meet the challenges likely to arise from an aging population.

First, the coming decades will witness sizable increases in the share of the population aged 65 and over, an age range in which many workers leave their longer-term career jobs and move into part-time or shorter-term jobs. As a consequence, potential problems stemming from age discrimination in hiring may became more important than they have been in past decades, when the baby boom was moving through the 40-64 age range - particularly in light of a public policy imperative to encourage continued employment of older individuals. The evidence on both enforcement and effectiveness of the ADEA is troublesome in this regard, because it suggests that the ADEA may be relatively ineffective with regard to hiring of older workers. There may be limitations on how effectively the regulatory and legal system addresses discrimination in hiring, and it would be useful to consider whether this effectiveness can be increased. The structure of civil rights laws and regulations provides not only for the same legal remedies available with regard to age discrimination, but also for affirmative action intended to actively encourage hiring of groups that have experienced discrimination in the past. While controversial, this does at least provide an example of how hiring discrimination can be addressed more directly. On the other hand, in crafting any policy changes intended to boost hiring of older workers, it is important to be mindful of underlying economic barriers to this hiring, and to try to focus on rooting out only the discriminatory behavior.

Second, with an increasing share of the population aged 65 and over, an increasing 
number of workers will be eligible for Medicare. Coupled with rising health insurance costs, increasing the ability of employers to rely on Medicare for health insurance for eligible workers seems likely to make workers aged 65 and over more attractive. Recent EEOC regulations have made it easier to wrap health insurance benefits around Medicare for retiree health plans. There may be some merit to thinking about whether similar accommodation should be made for current employees eligible for Medicare. However, if most workers in this age group seek and can find part-time work without health insurance benefits, then the problem may be mitigated.

Third, because disability rates rise with age, the aging of the population implies that a rising share of workers covered by the ADEA may also experience work-limiting disabilities. Hence employers may have to be concerned with discrimination claims brought under the ADA as well as the ADEA, especially because claims brought under the ADA may be more likely to be successful. There is some evidence that the combined impact of workers being protected by both laws is to reduce employment for those aged 65 and over, in which case the ADA may to some extent put a brake on the ability of the ADEA to help meet the challenge of trying to increase employment in an aging population. There is not an obvious simple way out of this conundrum, but if further investigation reveals it to be real problem, then an important challenge will be thinking creatively about how to continue to protect the aged and disabled from employment discrimination while not scaring employers away from hiring older workers who are relatively likely to experience some disability as they age. 


\section{References}

Abraham, Katharine G. and Susan N. Houseman. 2005. "Work and Retirement Among Older Americans.” Pp. 70-91 in Reinventing the Retirement Paradigm, edited by Robert L. Clark and Olivia S. Mitchell. New York: Oxford University Press.

Acemoglu, Daron and Joshua D. Angrist. 2001. "Consequences of Employment Protection? The Case of the Americans with Disabilities Act.” Journal of Political Economy 109:915-957.

Adams, Scott J. 2007. “Health Insurance Market Reform and Employee Compensation: The Case of Pure Community Rating in New York.” Journal of Public Economics 91:1119-1133.

------. 2004. “Age Discrimination Legislation and the Employment of Older Workers.” Labour Economics 11:219-241.

------. 2002. "Passed Over for Promotion Because of Age: An Empirical Analysis of the Consequences.” Journal of Labor Research 23:447-461.

Baicker, Katherine and Amitabh Chandra. 2005. “The Labor Market Effects of Rising Health Insurance Premiums.” NBER Working Paper No. 11160.

Beegle, Kathleen and Wendy A. Stock. 2003. “The Labor Market Effects of Disability Discrimination Laws.” Journal of Human Resources 38:806-859.

Bendick, Marc, Jr., Lauren E. Brown, and Kennington Wall. 1999. "No Foot in the Door: An Experimental Study of Employment Discrimination Against Older Workers.” Journal of Aging \& Social Policy 10:5-23.

Bendick, Marc, Jr., Charles W. Jackson, and J. Horacio Romero. 1996. “Employment Discrimination Against Older Workers: An Experimental Study of Hiring Practices.” Journal of Aging \& Social Policy 8:25-46.

Bloch, Farrell. 1994. Antidiscrimination Law and Minority Employment. Chicago, IL: University of Chicago Press. 
Cahill, Kevin E., Michael D. Giandrea, and Joseph F. Quinn. 2005. “Are Traditional Retirements a Thing of the Past? New Evidence on Retirement Patterns and Bridge Jobs.” Unpublished manuscript, Tinari Economics Group, New York.

Cornwell, Christopher, Stuart Dorsey, and Nasser Mehrzad. 1991. “Opportunistic Behavior by Firms in Implicit Pension Contracts.” Journal of Human Resources 26:704-725.

Deleire, Thomas. 2000. "The Wage and Employment Effects of the Americans with Disabilities Act.” Journal of Human Resources 35:693-715.

Finkelstein, L. M, M. J. Burke, and N. S. Raju. 1995. “Age Discrimination in Simulated Employment Contexts: An Integrative Analysis.” Journal of Applied Psychology 80:652-663.

Friedberg, Leora and Anthony Webb. 2003. "Retirement and the Evolution of Pension Structure.” NBER Working Paper No. 9999, Cambridge, MA.

Friedman, Lawrence M. 1984. Your Time Will Come: The Law of Age Discrimination and Mandatory Retirement. Social Research Perspectives Occasional Report. New York: Russell Sage Foundation.

Goda, Gopi Shah, John B. Shoven, and Sita Nataraj Slavov. 2007. “A Tax on Work for the Elderly: Medicare as a Secondary Payer.” NBER Working Paper No. 13383, Cambridge, MA.

Gordon, Randall A. and Richard D. Arvey. 2004. "Age Bias in Laboratory and Field Settings: A Meta-Analytic Investigation.” Journal of Applied Social Psychology 34:468-492.

Gottschalk, Peter T. 1982. “Employer-Initiated Job Terminations,” Southern Economic Journal 49:35-44.

Gustman, Alan L. and Thomas L. Steinmeier. 2000. "Retirement Outcomes in the Health and Retirement Study.” Social Security Bulletin 63:57-71.

Heckman, James J. 1998. “Detecting Discrimination.” Journal of Economic Perspectives 12:101116. 
Hellerstein, Judith and David Neumark. "Production Function and Wage Equation Estimation with Heterogeneous Labor: Evidence from a New Matched Employer-Employee Data Set.” Pp. 31-71 in Hard-to-Measure Goods and Services: Essays in Memory of Zvi Griliches, edited by Charles Hulten and Ernst Berndt. Chicago, IL: University of Chicago Press.

Hirsch, Barry T., David A. Macpherson, and Melissa Hardy. 2000. “Occupational Age Structure and Access for Older Workers.” Industrial and Labor Relations Review 53:401-418.

Hutchens, Robert M. 1987. “A Test of Lazear’s Theory of Delayed Payment Contracts.” Journal of Labor Economics 5:S153-S170.

------. 1986. "Delayed Payment Contracts and a Firm’s Propensity to Hire Older Workers.” Journal of Labor Economics 4:439-457.

Issacharoff, Samuel and Erica W. Harris. 1997. "Is Age Discrimination Really Age Discrimination? The ADEA’s Unnatural Solution.” New York University Law Review 72:780840.

Johnson, Richard W. and David Neumark. 1997. “Age Discrimination, Job Separations, and Employment Status of Older Workers.” Journal of Human Resources 32:779-811.

Jolls, Christine. 1996. "Hands-Tying and the Age Discrimination in Employment Act.” Texas Law Review 74:1813-1846.

Jolls, Christine and J. J. Prescott. 2005. "Disaggregating Employment Protection: The Case of Disability Discrimination.” Harvard Public Law Working Paper No. 106, Cambridge, MA.

Kite, Mary E., Gary D. Stockdale, Bernard E. Whitley, Jr., and Blair T. Johnson. 2005. “Attitudes Toward Younger and Older Adults: An Updated Meta-Analytic Review.” Journal of Social Issues 61:241-266.

Kotlikoff, Laurence J. and Jagadeesh Gokhale. 1992. “Estimating a Firm’s Age-Productivity Profile Using the Present Value of Workers' Earnings.” Quarterly Journal of Economics 
107:1215-1242.

Lahey, Joanna. 2008. “Age, Women, and Hiring: An Experimental Study.” Journal of Human Resources 43:30-56.

------. 2007. "Does Health Insurance Affect the Employment of Older Workers?” Issue Brief 08, The Center on Aging \& Work at Boston College, Chestnut Hill, MA.

------. "State Age Protection Laws and the Age Discrimination in Employment Act.”

Forthcoming in Journal of Law and Economics.

Lazear, Edward P. 1995. Personnel Economics. Cambridge, MA: The MIT Press.

------. 1979. “Why Is There Mandatory Retirement?” Journal of Political Economy 87:12611284.

Lazear, Edward P. and Robert L. Moore. 1984. “Incentives, Productivity, and Labor Contracts.” Quarterly Journal of Economics 99:275-296.

Miller, D. 1966. “Age Discrimination in Employment: The Problem of the Older Worker.” New York University Law Review 41:383-424.

Neumark, David. 2008. “Reassessing the Age Discrimination in Employment Act.” AARP Public Policy Institute, Washington, DC.

------. 2006. "Productivity, Compensation, and Retirement.” Pp. 721-739, in The Oxford

Handbook of Pensions and Retirement Income, edited by Gordon L. Clark, Alicia H. Munnell, and J. Michael Orszag. Oxford, UK: Oxford University Press.

-----. 2003. “Age Discrimination Legislation in the United States.” Contemporary Economic Policy 21:297-317.

-----. 1996. “Sex Discrimination in Restaurant Hiring: An Audit Study.” Quarterly Journal of Economics 111:915-91.

Neumark, David and Wendy A. Stock. 1999. “Age Discrimination Laws and Labor Market 
Efficiency.” Journal of Political Economy 107:1081-1125.

Papke, Leslie E. 1997. “Quantifying the Substitution of 401(k) Plans for Defined Benefit Plans: Evidence from Ongoing Employers.” National Tax Association $89^{\text {th }}$ Annual Conference on Taxation, pp. 136-44.

Penner, Rudolph G., Pamela Perun, and Eugene Steuerle. 2002. “Legal and Institutional Impediments to Partial Retirement and Part-Time Work by Older Workers.” Washington, DC: Urban Institute.

Posner, Richard A. 1995. Aging and Old Age. Chicago, IL: University of Chicago Press.

Riach, P. A. and J. Rich. 2002. "Field Experiments of Discrimination in the Market Place.” Economic Journal 112:F480-F518.

Scott, Frank A., Mark C. Berger, and John E. Garen. 1995. "Do Health Insurance and Pension Costs Reduce the Job Opportunities of Older Workers?” Industrial and Labor Relations Review 48:775-791.

Sheiner, Louise. 1999. "Health Care Costs, Wages, and Aging.” Unpublished paper, Federal Reserve Board of Governors, Washington, DC.

Spero, Donald J. 2006. “Smith v. City of Jackson: Does It Really Open New Opportunities for ADEA Plaintiffs to Recover Under a Disparate Impact Theory?” University of Memphis Law Review 36:183-216.

Stock, Wendy A. and Kathleen Beegle. 2004. "Employment Protections for Older Workers: Do Disability Discrimination Laws Matter?” Contemporary Economic Policy 22:111-126.

U.S. Department of Labor. 1965. The Older American Worker. Washington, DC: Government Printing Office.

Wiatrowski, William J. 2001. “Changing Retirement Age: Ups and Downs.” Monthly Labor Review 124:3-12. 
Figure 1: Actual and Projected Population Shares of Those Aged 20+ by Age
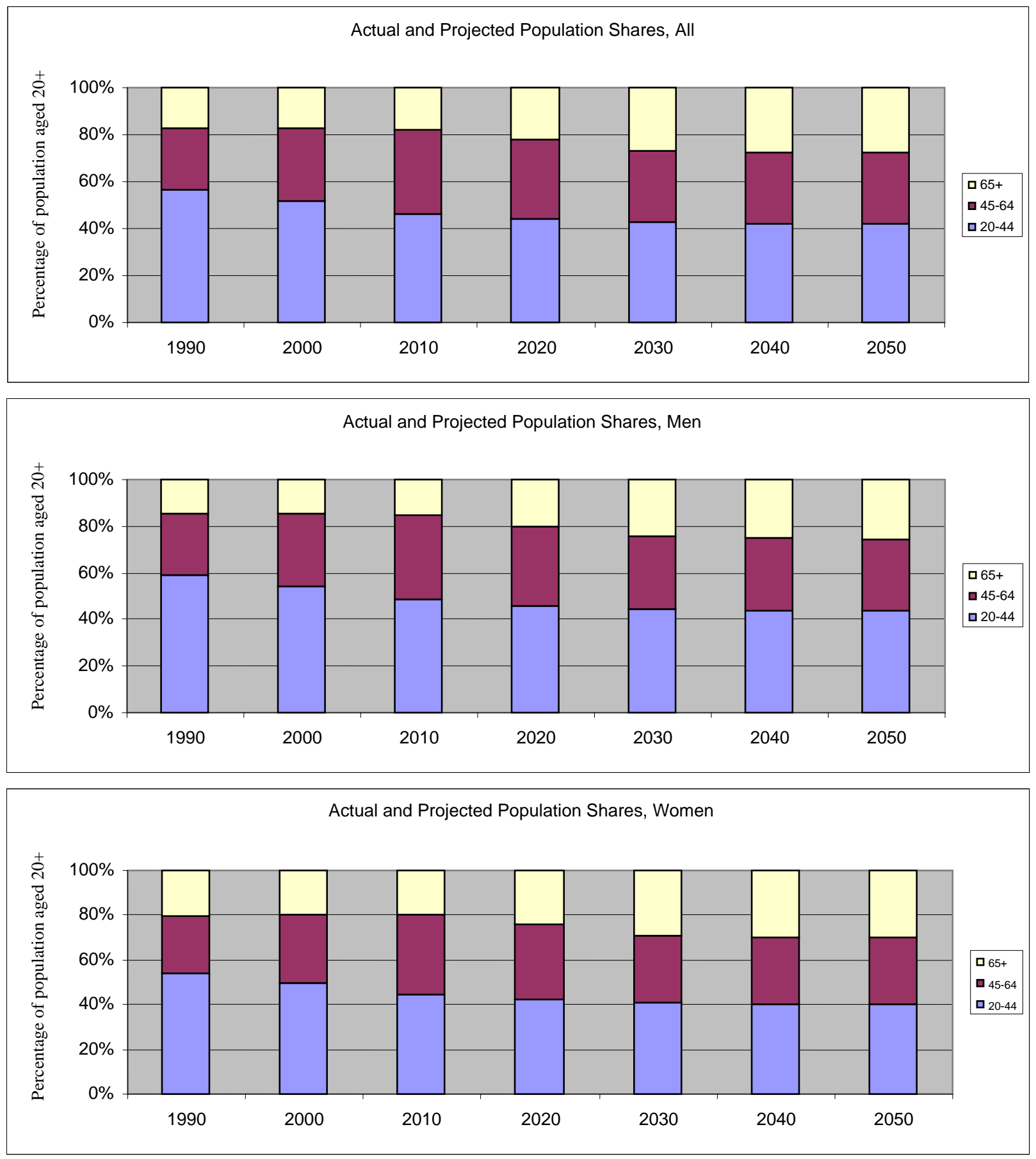

Source: U.S. Census Bureau Population Estimates (www.census.gov/popest/archives/1990s/natagesex.txt, viewed August 13, 2007), and U.S. Census Bureau Interim Projections (www.census.gov/ipc/www/usinterimproj, viewed August 8, 2007). 
Table 1: EEOC Receipt of Discrimination Charges, 2006 Fiscal Year

\begin{tabular}{|c|c|c|c|c|}
\hline & Total $^{\mathrm{a}}$ & ADEA & ADA & Title VII \\
\hline & $(1)$ & $(2)$ & (3) & (4) \\
\hline Total allegations $^{\mathrm{b}}$ & 143,686 & 22,931 & 23,708 & 96,070 \\
\hline \multicolumn{5}{|l|}{ Issues alleged (percent) ${ }^{\mathrm{C}}$} \\
\hline Benefits & .9 & 1.5 & 1.4 & .7 \\
\hline Demotion & 1.8 & 2.7 & 1.4 & 1.7 \\
\hline Discharge & 31.6 & 36.8 & 35.9 & 29.5 \\
\hline Discipline & 5.3 & 4.8 & 4.1 & 5.7 \\
\hline Harassment & 16.1 & 8.6 & 8.0 & 20.0 \\
\hline Hiring & 4.2 & 8.4 & 4.9 & 3.1 \\
\hline Layoff & 1.6 & 3.6 & 1.7 & 1.2 \\
\hline Promotion & 4.6 & 6.0 & 1.7 & 5.0 \\
\hline Reasonable accommodation & 3.3 & & 18.3 & .5 \\
\hline Retirement-involuntary & .2 & .6 & .2 & .04 \\
\hline Severance pay denied & .05 & .1 & .08 & .03 \\
\hline Terms/conditions & 13.1 & 12.4 & 9.3 & 14.3 \\
\hline Wages & 4.1 & 3.3 & 1.3 & 4.2 \\
\hline Waivers & .09 & .15 & .13 & .06 \\
\hline Other & 13.1 & 11.2 & 11.6 & 14.0 \\
\hline Discharge + layoff & 33.2 & 40.4 & 37.6 & 30.7 \\
\hline \multicolumn{5}{|c|}{$\begin{array}{l}\text { Source: Data supplied by the EEOC. Cases can be filed under multiple statutes, su } \\
\text { as the ADEA and the ADA. } \\
\text { aTotal also include Equal Pay Act and a handful of unspecified charges. } \\
\text { bTotal allegations can exceed number of charges, because a charge can include } \\
\text { allegations under more than one statute. } \\
\text { "All issues that appear for age cases, as well as "Reasonable accommodation," are } \\
\text { shown. }\end{array}$} \\
\hline
\end{tabular}


Table 2: EEOC Litigation Activity, 2006 Fiscal Year

\begin{tabular}{|c|c|c|c|c|c|}
\hline & \multicolumn{4}{|c|}{ Bases alleged $^{\mathrm{a}}$} \\
\hline & Total & Age & Disability & Race & Sex \\
\hline & (1) & (2) & (3) & (4) & (5) \\
\hline \multicolumn{6}{|l|}{ Merit filings ${ }^{\mathrm{b}}$} \\
\hline Total & 383 & 43 & 49 & 81 & 180 \\
\hline Individual & 244 & & & & \\
\hline Class & 139 & & & & \\
\hline \multicolumn{6}{|l|}{ Issues alleged ${ }^{c}$} \\
\hline Benefits & 5 & 4 & & & \\
\hline Demotion & 9 & 3 & & 1 & 2 \\
\hline Discharge & 239 & 24 & 28 & 32 & 61 \\
\hline Discipline & 15 & 1 & 2 & 5 & \\
\hline Harassment & 160 & 7 & & 37 & 105 \\
\hline Hiring & 50 & 10 & 10 & 7 & 20 \\
\hline Layoff & 14 & 4 & & 3 & 6 \\
\hline Promotion & 22 & 5 & 2 & 10 & 5 \\
\hline Reasonable accommodation & 29 & & 19 & & \\
\hline Retirement-involuntary & 2 & 2 & & & \\
\hline Severance pay denied & 1 & 1 & & & \\
\hline Terms/conditions & 33 & 4 & & 12 & 13 \\
\hline Wages & 13 & & & 5 & \\
\hline Waivers & 3 & 1 & & & 7 \\
\hline Other & 39 & & 3 & 9 & 6 \\
\hline Discharge + layoff \% & $66 \%$ & $65 \%$ & $57 \%$ & $43 \%$ & $37 \%$ \\
\hline Hiring \% & $13 \%$ & $23 \%$ & $20 \%$ & $9 \%$ & $11 \%$ \\
\hline
\end{tabular}

Source: Data supplied by the EEOC. There are other bases not included in this table, so the second through fifth columns do not add up to the first. On the other hand, a suit may allege multiple bases for discrimination.

aThere are also numerous "retaliation” cases, which charge discrimination "against individuals who oppose unlawful discrimination or participate in an employment discrimination proceeding” (www.eeoc.gov/types/retaliation.html).

${ }^{b}$ Merit filings include mainly direct lawsuits, and a handful of other interventions and actions to enforce conciliation agreements.

"All issues that appear for age cases, as well as "Wages” and "Reasonable accommodation," are shown. 
Table 3: Unemployment Durations by Age, 2006

\begin{tabular}{|c|c|c|c|c|}
\hline & \multicolumn{4}{|c|}{ Percentage with unemployment duration } \\
\hline & $\begin{array}{c}<5 \\
\text { weeks }\end{array}$ & $\begin{array}{c}\text { 5-14 } \\
\text { weeks }\end{array}$ & $\begin{array}{l}\text { 15-26 } \\
\text { weeks }\end{array}$ & $\begin{array}{c}\geq 27 \\
\text { weeks }\end{array}$ \\
\hline & (2) & (3) & (4) & (5) \\
\hline All & & & & \\
\hline $16-19$ & 46.9 & 33.2 & 10.7 & 9.2 \\
\hline $20-24$ & 41.6 & 30.1 & 13.9 & 14.5 \\
\hline $25-34$ & 36.9 & 31.4 & 15.5 & 16.2 \\
\hline $35-44$ & 34.1 & 29.8 & 15.9 & 20.2 \\
\hline $45-54$ & 30.0 & 29.9 & 17.3 & 22.9 \\
\hline $55-64$ & 31.8 & 25.0 & 15.3 & 27.9 \\
\hline $65+$ & 38.4 & 27.0 & 13.8 & 20.8 \\
\hline Men & & & & \\
\hline $16-19$ & 46.1 & 32.3 & 11.1 & 10.6 \\
\hline $20-24$ & 40.0 & 29.4 & 14.2 & 16.6 \\
\hline $25-34$ & 36.8 & 31.1 & 15.7 & 16.4 \\
\hline $35-44$ & 34.1 & 29.9 & 15.3 & 20.6 \\
\hline $45-54$ & 30.1 & 28.3 & 17.2 & 24.6 \\
\hline $55-64$ & 31.4 & 24.2 & 15.1 & 29.2 \\
\hline $65+$ & 39.8 & 25.0 & 12.5 & 22.7 \\
\hline Women & & & & \\
\hline $16-19$ & 48.0 & 34.3 & 10.3 & 7.5 \\
\hline $20-24$ & 43.6 & 31.1 & 13.4 & 11.7 \\
\hline $25-34$ & 37.1 & 31.6 & 15.3 & 15.9 \\
\hline $35-44$ & 33.9 & 29.7 & 16.6 & 19.8 \\
\hline $45-54$ & 30.0 & 31.7 & 17.4 & 21.2 \\
\hline $55-64$ & 32.5 & 26.0 & 15.5 & 26.4 \\
\hline $65+$ & 38.0 & 29.6 & 15.5 & 18.3 \\
\hline
\end{tabular}

Source: Employment and Earnings

(www.bls.gov/cps/home.htm\#annual, viewed August 8, 2007). 


\section{Endnotes}

${ }^{1}$ I provide a broader review of age discrimination legislation in the United States and related research in Neumark (2003); here, I emphasize newer research.

${ }^{2}$ See www.bls.gov/cps/home.htm\#annual, viewed August 8, 2007.

${ }^{3}$ A related concept is that of "phased retirement" (e.g., Wiatrowski 2001), whereby older employees continue with their current employer but are rehired as consultants or parttime/seasonal workers, reduce their hours, enter job-sharing arrangements, or move to less stressful jobs, etc., while partially drawing on their pensions. The ability of employers to implement phased retirement probably depends more on ERISA and the IRS code, although Penner et al. (2002) suggest that murkiness in the ADEA's treatment of retirement benefits could deter employers from implementing phased retirement.

${ }^{4}$ For details, see http://www.eeoc.gov/charge/overview_charge_filing.html and http://www.eeoc.gov/charge/overview_charge_processing.html, viewed October 22, 2007. ${ }^{5}$ According to EEOC regulations, when there is a state age discrimination law, the charge is “dual filed” with the EEOC if the individual files a charge with the FEP, and vice versa. The intent is to reduce duplication of effort. However, the charge is usually retained by the jurisdiction with which the charge is filed. (See www.eeoc.gov/charge/overview_charge_filing.html, viewed October 23, 2007.) Because of differences in state laws, there may sometimes be a better chance of prevailing by filing under a state law. For example, in some states age discrimination is covered under a human rights statute with no provision for a defense that outcomes correlated with age are based on "reasonable factors other than age" (http://www.dorsey.com/publications/legal_detail.aspx?FlashNavID=pubs_legal\&pubid=1880 
61603, viewed October 23, 2007).

${ }^{6}$ Of course EEOC litigation represents only a fraction of the total number of discriminationrelated lawsuits, which includes a much larger number brought by private attorneys. On the other hand, according to the EEOC the success rate of their lawsuits is far higher than that in suits brought by private attorneys (www.eeoc.gov/press/8-13-02.html, viewed August 23 2007), which likely reflects the EEOC choosing the strongest cases that it thinks it can win, as well as perhaps the greater difficulty of prevailing against the EEOC.

${ }^{7}$ For discussion of these issues, see, e.g., Bloch (1994), Issacharoff and Harris (1997), and Posner (1995).

${ }^{8}$ See www.eeoc.gov/policy/regs/retiree_benefits/qanda-retireehealthbenefits.html, viewed August 15, 2007.

${ }^{9}$ Code of Federal Regulations, Title 29, Section 1625.10.

10 “Disparate impact” refers to practices that may not have discriminatory intent, but have an unjustified adverse impact on members of a protected class.

${ }^{11}$ Note that some state laws, such as in Minnesota, explicitly allowed disparate impact cases before (see www.humanrights.state.mn.us/rsonline7/overview.html, viewed August 29, 2007). 12 The report argued that age discrimination was not driven by animus toward older workers, but rather by assumptions "about the effect of age on [workers'] ... ability to do a job when there is in fact no basis for those assumptions” (p. 20, bracketed phrase added).

${ }^{13}$ Note, though, that even if we view the data on durations as possibly indicating discrimination against older individuals looking for work, the problem is not most severe for those aged 65 and over - the group that will represent a growing share of the potential workforce in coming decades. 
${ }^{14}$ Earlier research used these methods to study discrimination by race, ethnicity, and sex. See, e.g., Fix and Struyk (1993), Heckman (1998), Neumark (1996), and Riach and Rich (2002).

${ }^{15}$ Johnson and Neumark (1997) studied self-reported age discrimination in earlier work.

${ }^{16}$ In addition to the types of evidence discussed here, one might note that the large volume of age discrimination litigation decided in favor of plaintiffs suggests the existence of such discrimination. This argument has some merit, although it at best can establish isolated cases of discrimination, rather than telling us anything about the pervasiveness of such discrimination.

${ }^{17}$ In particular, in states that do not have their own statutes, workers must file a claim with the EEOC within 180 days, whereas when the state has its own statute and an FEP commission or agency, the worker has 300 days to file with the state's FEP agency or the EEOC. Lahey argues that that law has permitted workers to file with both the EEOC and the state FEP within 300 days. However, some states have shorter filing deadlines, and it is not apparent that a claim filed after the state deadline will be considered by the state FEP.

${ }^{18}$ As noted earlier, state laws also sometimes differ in terms of the types of defenses they allow. This variation is conceivably more important than differences in the length of time to file claims.

${ }^{19}$ There is a good deal of research documenting evidence consistent with Lazear's model, including, for example, evidence presented in his original paper, as well as in Lazear and Moore (1984), Hutchens (1987), Kotlikoff and Gokhale (1992), and Hellerstein and Neumark (2007).

${ }^{20}$ Lazear does not explicitly label reneging on long-term implicit contracts as "age discrimination.” But this kind of firm cheating has been characterized as discrimination in 
other work, such as Gottschalk (1982), who explores the conditions under which this is more or less likely to occur, and Cornwell, Dorsey, and Mehrzad (1991), who focus on age discrimination in terminations.

${ }^{21}$ Jolls (1996) makes a similar argument. Neumark and Stock also contend that the increase in the mandatory retirement age was less important, based on earlier work suggesting it had little effect on retirement behavior.

${ }^{22}$ See, e.g., Papke (1997) and Friedberg and Webb (2003). Neumark (2006) discusses some of the hypotheses regarding why this change occurred.

${ }^{23}$ On the other hand, increases in state health insurance mandates - such as for infertility treatment - or policy changes such as the introduction of pure community rating (Adams 2007) - which prevents insurance carriers from charging different premiums based on the ages of a firm’s workforce - may increase the relative cost of insuring younger workers.

${ }^{24}$ In contrast, for retiree health plans Medicare is the primary payer.

${ }^{25}$ Scott et al. (1995) present evidence from the 1979-1991 period that firms offering health care plans were less likely to hire workers aged 55-64. See also Goda et al. (2007), who suggest that the Medicare as Secondary Payer rule leads to lower wages for workers aged 65 and over, which in turn reduces labor supply substantially.

${ }^{26}$ Jolls and Prescott's conclusions are more mixed. However, they find no longer-term disemployment effects. 